\title{
The Eternal Battle between Microbes and Humans
}

\author{
Mostafa FN Abushahba* \\ Department of Animal Hygiene \& Zoonoses, Assiut University Asyut, Egypt
}

Received: January 30, 2018; Published: February 07, 2018

*Corresponding author: Mostafa FN Abushahba, Department of Animal Hygiene \& Zoonoses, Faculty of Veterinary Medicine, Assiut University Asyut 71526, Egypt, Email: mateya@aun.edu.eg

\section{Introduction}

In 1950s, practitioners believed that the age-old battle of mankind with microbes was finally stopped. Shortly thereafter that concept has been completely changed following the occurrence of major outbreaks caused either by new pathogens or traditional resurging agents with a potential global spread [1]. Depending on their evolutionary dynamics, the ability of microorganisms to cause diseases is rapidly changing and increasing over time [2]. One potential example is the pathogens of animal origin (i.e. zoonotic diseases) that have accounted for more than two thirds among of emerging human infections, and therefore constitute a serious human health hazard [3,4]. Disease emergence involves the appearance of new pathogens as well as re-emergence of already known ones [5]. The transfer of diseases to humans from food animals is a particular problem and the situation is aggravated by the spread of pathogens carrying resistomes (i.e. antimicrobial resistant genes) such as Salmonella, E. coli and Staphylococcus aureus in food-producing animals owing to the overuse of antimicrobials which present a public health risk by the transfer of such resistant pathogens eventually to humans $[6,7]$.

Additionally, recent research has suggested that certain microbes which have known as strictly human or animal pathogens for a long time may be changing their epidemiology, underscoring the urgent need for careful source tracking. An example is Clostridium difficile which has been known since 1970 s as a nosocomial pathogen in health care facilities affecting elderly and hospitalized patients worldwide [8] and producing diarrhea, pseudomembranous colitis, toxic megacolon, and death, especially after antibiotic therapy [9]. In recent years, C. difficile has alarmed public health officials by emerging as a community acquired pathogen outside the healthcare settings among young and relatively healthy individuals without known predisposing factors or classified as a low risk e.g. children and pregnant women [10]. The zoonotic origin of C. difficile is possible especially with the increasing reports of its isolation from various animals such as pigs, calves, horses, poultry, and pet animals [11]. On the other hand, the host range of another zoonotic pathogen, hepatitis E virus, (the natural reservoir is swine) has expanded to involve more species such as cattle, and such expanded host selection may constitute an additional zoonotic risk to human [12]. Early detection of zoonotic pathogens and description of their associated resistomes will be a priority in controlling unprecedented outbreaks in the coming decades especially with the continuous evolution of pathogens as a result of environmental changes and medical interventions [13]. Traditionally, microbes and their associated resistomes can be identified by a wide range of conventional and molecular techniques however, given their capability in rapid and simultaneous detection of multiple pathogens in a single test, detection of pathogens at a very low numbers, and identifying novel pathogens as well as detection of the transmission events, the culture-independent approaches (such as 16S ribosomal RNA and metagenomics) hold a future promise as alternatives to the traditional methods in pathogen detection and characterization [14].

\section{References}

1. Oppong JR (2010) Emerging and reemerging pandemics. In: Gritzner CF (Eds.). Glob Connect. Pandemics Glob Heal, Infobase Publishing, New York, USA, p. 96.

2. Fauci AS, Morens DM (2012) The Perpetual Challenge of Infectious Diseases. N Engl J Med 366(5): 454-461.

3. Temmam S, Davoust B, Berenger JM, Raoult D, Desnues C (2014) Viral metagenomics on animals as a tool for the detection of zoonoses prior to human infection? Int J Mol Sci 15(6): 10377-10397.

4. Cutler SJ, Fooks AR, Van Der Poel WHM (2010) Public health threat of new, reemerging, and neglected zoonoses in the industrialized world. Emerg Infect Dis 16(1): 1-7.

5. Iamsirithaworn S, Chanachai K, Castellan D (2014) Confronting Emerging Zoonoses the One Health Paradigim. Springer.

6. Weese JS (2010) Methicillin-resistant Staphylococcus aureus in animals. ILAR J 51(3): 233-244.

7. Tollefson L, Angulo FJ, Fedorka Cray PJ (1998) National surveillance for antibiotic resistance in zoonotic enteric pathogens. Vet Clin North Am Anim Pract 14(1): 141-150.

8. Rupnik M, Wilcox MH, Gerding DN (2009) Clostridium difficile infection: new developments in epidemiology and pathogenesis. Nat Rev Microbiol 7(7): 526-536. 
9. Indra $A$, Lassnig H, Baliko N, Much P, Fiedler A, et al. (2009) Clostridium difficile: A new zoonotic agent? Wien Klin Wochenschr 121(3-4): 91-95.

10. Bloomfield LE, Riley TV (2016) Epidemiology and Risk Factors for Community-Associated Clostridium difficile Infection: A Narrative Review. Infect Dis Ther Springer Healthcare 5(3): 231-251.

11. Rodriguez Palacios A, Borgmann S, Kline TR, LeJeune JT (2013) Clostridium difficile in foods and animals: history and measures to reduce exposure. Anim Health Res Rev 14(1): 11-29.
12. Huang F, Li Y, Yu W, Jing S, Wang J, et al. (2016) Excretion of infectious hepatitis $\mathrm{E}$ virus into milk in cows imposes high risks of zoonosis. Hepatology 64(2): 350-359.

13. Leventhal GE, Hill AL, Nowak MA, Bonhoeffer S (2015) Evolution and emergence of infectious diseases in theoretical and real-world networks. Nat Commun 6: 6101.

14. Miller RR, Montoya V, Gardy JL, Patrick DM, Tang P (2013) Metagenomics for pathogen detection in public health. Genome Med 5(9): 81.

Assets of Publishing with us
BIOMEDICAL
RESEARCHES

